\title{
SISTEM INFORMASI PERHITUNGAN POIN PELANGGARAN SISWA MENGGUNAKAN METODE SIMPLE ADDITIVE WEIGHTING (SAW) (Studi Kasus Di SMK As-Shofa Kabupaten Tasikmalaya)
}

\author{
Candra Surya $^{1}$, Asep Wahyu ${ }^{2}$ \\ ${ }^{1}$ Manajemen Informatika, AMIK Mitra Gama \\ ${ }^{2}$ Sistem Informasi, STMIK Bandung \\ ${ }^{1}$ Jl. Kayangan No 99 Duri-Riau \\ ${ }^{2}$ Jl. Cikutra No 113 A Cibeunying Kidul, Bandung \\ Email :'candrasurya@gmail.com, 2asepwahyu727@gmail.com
}

\begin{abstract}
ABSTRAK
Pendidikan mempunyai peranan yang sangat penting dalam kehidupan manusia. Semakin tinggi pendidikan seseorang maka akan semakin tinggi wawasan dan pengetahuannya. Sekolah merupakan salah satu lembaga pendidikan formal tempat dimana anak menggali dan mengembangkan potensi yang ada pada dirinya. Dengan adanya pendidikan di sekolah diharapkan siswa tidak hanya menguasai materi pelajaran tetapi sekolah juga dituntut untuk dapat membentuk dan membina kepribadian siswa agar sesuai dengan nilai-nilai dan norma- norma yang berlaku dalam masyarakat. Oleh karena itu sebuah sistem pencatatan poin pelanggaran siswa pada sekolah sangat diperlukan dengan tujuan untuk mengetahui tingkat ketidak disiplinan para siswa dalam lingkungan sekolah. Sistem tersebut juga dapat menghasilkan informasi secara efektif dan efisien. Sistem informasi ini dirancang menggunakan metode Simple Additive Weighting (SAW). Metode ini digunakan untuk mencari alternatif dari sejumlah alternatif yang ada dengan kriteria-kriteria yang telah ditentukan oleh pengambil keputusan kemudian merangking dari alternatif yang ada. Dalam pengujian diambil sampel 5 orang siswa berdasarkan kriteria yang telah ditetapkan, hasil yang diperoleh diurut berdasarkan poin tertinggi. siswa $2=11,201$, siswa $3=10,665$, siswa $5=10,6$, siswa $4=8,366$ dan siswa $1=7,866$
\end{abstract}

Kata Kunci: Sistem Informasi, Perhitungan point, pelanggaran siswa, Simple Additive Weighting, SAW,

\section{Pendahuluan}

Pendidikan mempunyai peranan yang sangat penting dalam kehidupan manusia. Semakin tinggi pendidikan seseorang maka akan semakin tinggi wawasan dan pengetahuannya. Sekolah merupakan salah satu lembaga pendidikan formal tempat dimana anak menggali dan mengembangkan potensi yang ada pada dirinya. Dengan adanya pendidikan di sekolah diharapkan siswa tidak hanya menguasai materi perlajaran tetapi sekolah juga dituntut untuk dapat membentuk dan membina kepribadian siswa agar sesuai dengan nilai-nilai dan norma- norma yang berlaku dalam masyarakat. Dalam upaya mengoptimalkan kepribadian peserta didik, maka sekolah perlu menanamkan tata tertib terhadap siswa.
Keberadaan tata tertib sekolah berfungsi sebagai pedoman bagi siswa dalam berperilaku di lingkungan sekolah.

Seiring dengan berkembangnya pola perilaku siswa khususnya di SMK As-shofa Tasikmalaya, maka tidak mengherankan jika sering dijumpai siswa yang melanggar aturan dan tata tertib sekolah. Pelanggaran-pelanggaran yang bisa dijumpai di sekolah pada umumnya cukup beragam, diantaranya pelanggaran yang termasuk kedalam kategori ringan seperti datang terlambat, tidak mengerjakan pekerjaan rumah (PR), tidak mengikuti upacara, dan lain-lain, pelanggaran yang termasuk kategori sedang seperti membolos, merokok, berkelahi, dan pelanggaran yang termasuk kategori berat seperti terlibat tindakan kriminal, membawa atau memakai dan mengedarkan miras dan narkoba serta masih banyak lagi pelanggaran-pelanggaran lainnya. Tentunya telah menjadi tugas dan kewajiban guru, khususnya guru bimbingan konseling (BK) untuk memberikan pembinaan dan sanksi bagi siswa-siswa yang bermasalah.

Namun di beberapa sekolah khusunya di SMK Asshofa Tasikmalaya, perhitungan terhadap nilai poin pelanggaran siswa masih menggunakan sistem konvensional dimana guru BK harus mencatatat setiap pelanggaran siswa dalam sebuah buku besar dan menghitung nilai poin pelanggaran. Hal ini tentunya mengakibatkan sering terlambatnya proses penindaklanjutan terhadap siswa yang bermasalah, selain itu sering terjadi kesalahan dalam merekapitulasi poin pelanggaran siswa sehingga sanksi yang diberikan tidak sesuai dengan jumlah poin pelanggarannya.

Dalam rangka untuk membantu kinerja guru dalam menangani siswa yang bermasalah, maka penulis akan menganalisi dan merancang suatu sistem untuk menghitung Poin Pelanggaran Siswa Menggunakan Metode Metode Simple Additive Weighting (SAW).

\section{Tinjauan Pustaka}

Berdasarkan penelitian sebelumnya sebagai referensi dalam penelititan ini diambil dari beberapa penelitian lain yaitu Implementasi sistem pendukung keputusan penerimaan siswa baru menggunakan metode simple additive weighting, penelitian tersebut bertujuan membuat sebuah system informasi penerimaan siswa baru dengan menggunakan metode Simple Additive Weighting (SAW) yang memberikan hasil lebih optimal dalam pengelolaan dan perhitungan nilai sehingga pihak panitia 
dapat cepat memberikan keputusan [1]. Penelitian lainnya yaitu Sistem Pendukung Keputusan Kelayakan Calon Penerima Bantuan Bedah Rumah Di Kecamatan Sambirejo dengan Menggunakan Metode Simple Additive Weighting, Hasil dari penelitian ini berupa sistem pendukung keputusan penentuan penerima bantuan bedah rumah berdasarkan akumulasi kriteriakriteria yang telah ditentukan [2]. Penelitian lainnya yaitu Sistem Pendukung Keputusan Pemilihan Perguruan Tinggi Menggunakan Fuzzy Multi Attribute Decision Making (FMADM) dan Simple Additive Weighting (SAW). tujuan yang diharapkan dalam penelitian ini yaitu membangun suatu model pengambilan keputusan pemilihan perguruan tinggi menggunakan Fuzzy Mutiple Attribute Decision Making (FMADM) dengan metode Simple Addive Weighting (SAW) yang akan memberikan referensi kepada pengguna dalam menentukan perguruan tinggi [3].

\section{a. Simple Additive Weighting (SAW)}

Metode SAW sering juga dikenal dengan istilah metode penjumlahan terbobot [4]. Konsep dasar metode SAW adalah mencari penjumlahan terbobot dari rating kinerja pada setiap alternatif pada semua atribut [5]. Metode SAW proses normalisasi matrik keputusan (X) ke suatu skala yang dapat diperbandingkan dengan semua rating alternatif yang ada [6].

$$
\boldsymbol{r}_{\boldsymbol{i} \boldsymbol{j}=}\left\{\begin{array}{cc}
\frac{\boldsymbol{x}_{\boldsymbol{i} \boldsymbol{j}}}{\boldsymbol{M a x} \boldsymbol{x}_{\boldsymbol{i} \boldsymbol{j}}} & \text { Jika J adalah atribut } \\
\boldsymbol{i} & \text { keuntungan (benefit) } \\
\boldsymbol{M i n} \boldsymbol{x}_{\boldsymbol{i} \boldsymbol{j}} & \text { Jika J adalah atribut } \\
\hline \boldsymbol{i} & \text { biaya (cost) }
\end{array}\right.
$$

Dimana $r_{i j}$ adalah rating kinerja ternormalisasi dari alternatif $A_{i}$ pada atribut $C_{j} ; i=1,2, \ldots m$ dan $j=1,2, \ldots n$. Nilai preferensi untuk setiap alternatif $\left(V_{i}\right)$ diberikan sebagai :

$$
V_{i}=\sum_{j=i}^{n} w_{j} r_{i j}
$$

Nilai $\mathrm{V}_{\mathrm{i}}$ yang lebih besar mengindikasikan bahwa alternatif $A_{i}$ lebih terpilih.

Dimana :

$$
\begin{array}{ll}
V i & =\text { Rangking Untuk Setiap Alternatif } \\
w j & =\text { Nilai Bobot Dari Setiap Kriteria } \\
r i j & =\text { Nilai Rating Kinerja Ternormalisasi }
\end{array}
$$

b. Algoritma Penyelesaian SAW

Berikut ini adalah Algoritma yang dipakai dalam menyelesaikan permasalahan [7]:

1. Memberikan nilai setiap alternatif $\left(A_{i}\right)$ pada setiap kriteria $\left(C_{j}\right)$ yang sudah ditentukan,dimana nilai tersebut di peroleh berdasarkan nilai crisp $; i=1,2, \ldots$ m dan $j=1,2, \ldots . n$.

2. Memberikan nilai bobot $(W)$ yang juga didapatkan berdasarkan nilai crisp.

3. Melakukan normalisasi matriks dengan cara menghitung nilai rating kinerja ternormalisasi $\left(r_{i j}\right)$ dari alternatif $A i$ pada atribut $C_{j}$ berdasarkan persamaan yang disesuaikan dengan jenis atribut. Atribut keuntungan/benefit=MAKSIMUM atau atribut biaya/cost=MINIMUM. Apabila berupa artibut keuntungan maka nilai crisp $\left(X_{i j}\right)$ dari setiap kolom atribut dibagi dengan nilai crispMAX $\left(M A X X_{i j}\right)$ dari tiap kolom, sedangkan untuk atribut biaya, nilai crispMIN $\left(M I N X_{i j}\right)$ dari setiap kolom atribut dibagi dengan nilai $\operatorname{crisp}\left(X_{i j}\right)$ setiap kolom.

4. Melakukan proses perangkingan dengan cara mengalikan matriks ternormalisasi $(R)$ dengan nilai bobot $(W)$.

5. Menentukan nilai preferensi untuk setiap alternatif $\left(V_{i}\right)$ dengan cara menjumlahkan hasil kali antara matriks ternormalisasi $(R)$ dengan nilai bobot $(W)$. Nilai $V i$ yang lebih besar mengindikasikan bahwa alternatif $A_{i}$ lebih terpilih.

\section{Metodologi}

Penelitian dilakukan di SMK As-Shofa Kabupaten Tasikmalaya, data dikumpul menggunakan pendekatan deskriptif atau survey melalui guru bimbingan konseling (BP). Dalam ujicoba diambil sampel sebanyak 5 orang siswa. Data tersebut kemudian diolah, diuji dan dijadikan acuan dalam mengambil keputusan untuk menghitung point pelanggaran siswa menggunakan Metode Simple Additive Weighting (SAW). Adapun cara kerja pengujian menggunakan metode SAW sebagai berikut :

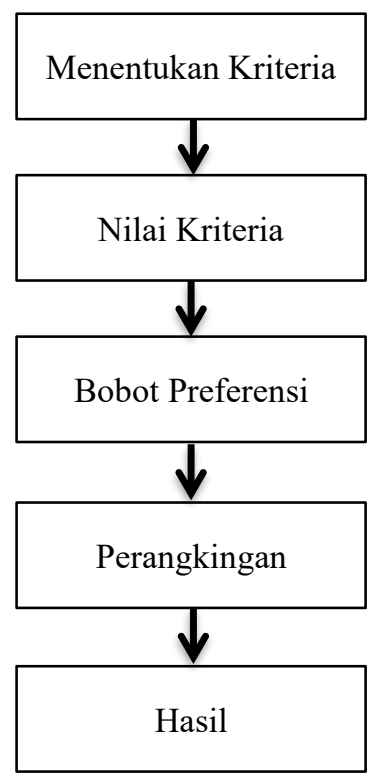

Gambar 1. Cara kerja pengujian 
Berdasarkan metode penelitian yaitu menggunakan metode SAW maka dibutuhkan 5 tahapan dalam menentukan point pelanggaran siswa.

Dalam pengujian tersebut diambil sampel sebanyak 5 orang siswa akan dijadikan alternatif dan dinilai berdasarkan tingkat kepentingan kriteria yang ada.

1. Menentukan kriteria sebagai pedoman dalam menilai tingkat pelanggaran siswa. Dalam hal ini dikelompokan menjadi 3 yaitu : sikap dan perilaku, kerajinan dan kerapian. Secara lengkap dapat dilihat pada tabel 1,2,3dibawah dibawah ini :

Tabel 1. Kriteria Sikap dan Perilaku

\begin{tabular}{|c|c|c|c|}
\hline No & Nama Kriteria & Bobot & $\begin{array}{c}\text { Ketera } \\
\text { ngan }\end{array}$ \\
\hline 1 & $\begin{array}{l}\text { Bertindak tidak sopan } \\
\text { kepada } \\
\text { sesama siswa }\end{array}$ & 4 & Rendah \\
\hline 2 & $\begin{array}{l}\text { Mengganggu ketenangan } \\
\text { KBM }\end{array}$ & 2 & $\begin{array}{l}\text { Sangat } \\
\text { Rendah }\end{array}$ \\
\hline 3 & $\begin{array}{l}\text { Membuang sampah tidak } \\
\text { pada } \\
\text { tempat yang semestinya }\end{array}$ & 5 & Cukup \\
\hline 4 & $\begin{array}{l}\text { Tidak } \\
\text { mengembalikan/menghil } \\
\text { angkan kunci kelas }\end{array}$ & 5 & Cukup \\
\hline 5 & $\begin{array}{l}\text { Mengancam/mengintimi } \\
\text { dasi guru, TU, dan siswa }\end{array}$ & 10 & Cukup \\
\hline 6 & $\begin{array}{l}\text { Mencoret dinding, meja, } \\
\text { kursi dan pagar }\end{array}$ & 10 & Cukup \\
\hline 7 & Meloncat pagar & 10 & Cukup \\
\hline 8 & $\begin{array}{l}\text { Bertindak tidak sopan } \\
\text { kepada guru/ karyawan }\end{array}$ & 10 & Cukup \\
\hline 9 & $\begin{array}{l}\text { Membawa/ merokok di } \\
\text { sekolah/ diluar sekolah } \\
\text { (masih }\end{array}$ & 15 & Tinggi \\
\hline 10 & $\begin{array}{lr}\text { Merusak } & \text { sarana/ } \\
\text { prasarana } & \text { sekolah, } \\
\text { software } & \text { maupun }\end{array}$ & 15 & Tinggi \\
\hline 11 & $\begin{array}{l}\text { Membawa HP, MP3, } \\
\text { MP4, Headset, atau } \\
\text { sejenisnya }\end{array}$ & 15 & Tinggi \\
\hline 12 & $\begin{array}{l}\text { Mengambil hak orang } \\
\text { lain, berjudi }\end{array}$ & 20 & Tinggi \\
\hline 13 & $\begin{array}{l}\text { Membawa senjata tajam, } \\
\text { senjata api dan } \\
\text { sejenisnya }\end{array}$ & 30 & Tinggi \\
\hline 14 & $\begin{array}{l}\text { Memalsukan tanda } \\
\text { tangan, nilai, dll }\end{array}$ & 30 & Tinggi \\
\hline 15 & $\begin{array}{l}\text { Berkelahi di lingkungan/ } \\
\text { diluar sekolah/ terlibat } \\
\text { tawuran antar sekolah }\end{array}$ & 30 & Tinggi \\
\hline
\end{tabular}

\begin{tabular}{|c|l|c|c|}
\hline 16 & $\begin{array}{l}\text { Pornografi atau } \\
\text { pornoaksi di ar diluar } \\
\text { lingkungan atau } \\
\text { sekolah }\end{array}$ & 50 & $\begin{array}{l}\text { Sangat } \\
\text { Tinggi }\end{array}$ \\
\hline 17 & $\begin{array}{l}\text { Membawa/ memakai/ } \\
\text { mengedarkan Miras dan } \\
\text { narkoba }\end{array}$ & 50 & $\begin{array}{l}\text { Sangat } \\
\text { Tinggi }\end{array}$ \\
\hline 18 & $\begin{array}{l}\text { Terlibat tindakan } \\
\text { criminal (sampai ditahan }\end{array}$ & 50 & $\begin{array}{l}\text { Sangat } \\
\text { Tinggi }\end{array}$ \\
\hline 19 & $\begin{array}{l}\text { Hamil/. menghamili// } \\
\text { nikah siri/ Tertangkap } \\
\text { tangan melakukan tindak }\end{array}$ & 100 & $\begin{array}{l}\text { Sangat } \\
\text { Tinggi }\end{array}$ \\
\hline
\end{tabular}

Tabel 2. Kriteria Kerajinan

\begin{tabular}{|c|l|c|c|}
\hline No & \multicolumn{1}{|c|}{ Nama Kriteria } & Bobot & $\begin{array}{c}\text { Ketera } \\
\text { ngan }\end{array}$ \\
\hline 1 & $\begin{array}{l}\text { Tidak mengerjakan tugas } \\
\text { PR }\end{array}$ & 1 & $\begin{array}{c}\text { Sangat } \\
\text { Rendah }\end{array}$ \\
\hline 2 & $\begin{array}{l}\text { Datang terlambat }<15 \\
\text { menit }\end{array}$ & 1 & $\begin{array}{c}\text { Sangat } \\
\text { Tinggi }\end{array}$ \\
\hline 3 & $\begin{array}{l}\text { Datang terlambat }<45 \\
\text { menit }\end{array}$ & 1 & $\begin{array}{c}\text { Sangat } \\
\text { Tinggi }\end{array}$ \\
\hline 4 & $\begin{array}{l}\text { Datang terlambat }>45 \\
\text { menit }\end{array}$ & 2 & Rendah \\
\hline 5 & $\begin{array}{l}\text { Tidak mengikuti } \\
\text { pelajaran tanpa ijin }\end{array}$ & 3 & Rendah \\
\hline 6 & $\begin{array}{l}\text { Meninggalkan kelas } \\
\text { tanpa ijin }\end{array}$ & 3 & Rendah \\
\hline 7 & $\begin{array}{l}\text { Tidak mengikuti siraman } \\
\text { rohani jumat pagi }\end{array}$ & 3 & Rendah \\
\hline 8 & $\begin{array}{l}\text { Tidak mengikuti } \\
\text { kegiatan } \\
\text { ekstrakulikuler/pengemb } \\
\text { angan diri }\end{array}$ & 3 & Rendah \\
\hline 9 & $\begin{array}{l}\text { Tidak masuk sekolah } \\
\text { tanpa keterangan/ keluar } \\
\text { sekolah sebelum jam } \\
\text { pulang tanpa ijin }\end{array}$ & 4 & Rendah \\
\hline
\end{tabular}

Tabel 3. Kriteria Kerapian

\begin{tabular}{|c|c|c|c|}
\hline No & Nama Kriteria & Bobot & $\begin{array}{c}\text { Ketera } \\
\text { ngan }\end{array}$ \\
\hline 1 & $\begin{array}{l}\text { Tidak memasukkan baju } \\
\text { seragam }\end{array}$ & 1 & $\begin{array}{l}\text { Sangat } \\
\text { Rendah }\end{array}$ \\
\hline 2 & Tidak memakai kaos kaki & 1 & $\begin{array}{l}\text { Sangat } \\
\text { Rendah }\end{array}$ \\
\hline 3 & $\begin{array}{l}\text { Tidak memakai ikat } \\
\text { pinggang }\end{array}$ & 1 & $\begin{array}{l}\text { Sangat } \\
\text { Rendah }\end{array}$ \\
\hline 4 & $\begin{array}{l}\text { Seragam atribut tidak } \\
\text { lengkap }\end{array}$ & 2 & Rendah \\
\hline 5 & $\begin{array}{l}\text { Tidak memakai sepatu } \\
\text { hitam/sepatu sekolah }\end{array}$ & 2 & Rendah \\
\hline
\end{tabular}




\begin{tabular}{|c|l|c|c|}
\hline 6 & $\begin{array}{l}\text { Berambut panjang } \\
\text { terberai (bagi siswa putri) }\end{array}$ & 2 & Rendah \\
\hline 7 & $\begin{array}{l}\text { Berambut gondrong (bagi } \\
\text { siswa putra) }\end{array}$ & 3 & Rendah \\
\hline 8 & $\begin{array}{l}\text { Bertindik,memakai } \\
\text { giwang (bagi siswa putra) }\end{array}$ & 5 & Cukup \\
\hline 9 & Bersolek berlebihan & 5 & Cukup \\
\hline 10 & $\begin{array}{l}\text { Baju seragam tidak sesuai } \\
\text { dengan ketentuan sekolah }\end{array}$ & 5 & Cukup \\
\hline 11 & Bertato & 10 & Cukup \\
\hline 12 & $\begin{array}{l}\text { Menggunakan pewarna } \\
\text { rambut }\end{array}$ & 10 & Cukup \\
\hline
\end{tabular}

Pada pengujian ini, penulis hanya mengambil 5 sampel dari kriteria diatas. Kriteria yang penulis gunakan dapat dilihat pada tabel 4 dibawah ini :

Tabel 7. Kriteria $\mathrm{C} 2$

\begin{tabular}{|l|l|c|}
\hline $\begin{array}{l}\text { Bertindak Tidak Sopan } \\
\text { Kepada Sesama Siswa }\end{array}$ & $\begin{array}{c}\text { Tingkat } \\
\text { Kepentingan }\end{array}$ & Nilai \\
\hline Tidak Benar & $\begin{array}{l}\text { Sangat } \\
\text { Rendah }\end{array}$ & 1 \\
\hline Benar & Rendah & 4 \\
\hline
\end{tabular}

Tabel 8. Kriteria C3

\begin{tabular}{|l|l|c|}
\hline $\begin{array}{l}\text { Membawa/ merokok di } \\
\text { sekolah/diluar sekolah }\end{array}$ & $\begin{array}{l}\text { Tingkat } \\
\text { Kepentingan }\end{array}$ & Nilai \\
\hline Tidak Benar & $\begin{array}{l}\text { Sangat } \\
\text { Rendah }\end{array}$ & 1 \\
\hline Benar & Cukup & 15 \\
\hline
\end{tabular}

Tabel 9. Kriteria C4

\begin{tabular}{|l|l|c|}
\hline $\begin{array}{l}\text { Membawa senjata tajam, } \\
\text { senjata api dan } \\
\text { sejenisnya }\end{array}$ & $\begin{array}{c}\text { Tingkat } \\
\text { Kepentingan }\end{array}$ & Nilai \\
\hline Tidak Benar & Sangat Rendah & 1 \\
\hline Benar & Tinggi & 30 \\
\hline
\end{tabular}

Tabel 10. Kriteria C5

\begin{tabular}{|c|l|}
\hline Kriteria & \multicolumn{1}{|c|}{ Keterangan } \\
\hline C1 & Mengganggu ketenangan KBM \\
\hline C2 & $\begin{array}{l}\text { Bertindak Tidak Sopan Kepada } \\
\text { Sesama Siswa }\end{array}$ \\
\hline C3 & $\begin{array}{l}\text { Membawa/ merokok di sekolah/ } \\
\text { diluar sekolah }\end{array}$ \\
\hline C4 & $\begin{array}{l}\text { Membawa senjata tajam, senjata } \\
\text { api dan sejenisnya }\end{array}$ \\
\hline C5 & Pornografi atau pornoaksi \\
\hline
\end{tabular}

Setelah kriteria ditentukan, selanjutnya penentuan tingkat kepentingan dan nilai bobot dari masing-masing kriteria (C1-C5):

2. Menentukan nilai dari masing-masing kriteria

Tabel 5. Tingkat Kepentingan Kriteria

\begin{tabular}{|c|c|}
\hline Tingkat Kepentingan & Bobot Nilai \\
\hline Sangat Tinggi & $31-100$ \\
\hline Tinggi & $16-30$ \\
\hline Sedang & $10-15$ \\
\hline Rendah & $2-9$ \\
\hline Sangat Rendah & 1 \\
\hline
\end{tabular}

Berikut nilai dari masing-masing kriteria berdasarkan tingkat kepentingan.

Tabel 6. Kriteria $\mathrm{C} 1$

\begin{tabular}{|l|l|c|}
\hline $\begin{array}{l}\text { Mengganggu ketenangan } \\
\text { KBM }\end{array}$ & $\begin{array}{l}\text { Tingkat } \\
\text { Kepentingan }\end{array}$ & Nilai \\
\hline Tidak Benar & $\begin{array}{l}\text { Sangat } \\
\text { Rendah }\end{array}$ & 1 \\
\hline Benar & Rendah & 2 \\
\hline
\end{tabular}

\begin{tabular}{|l|c|c|}
\hline $\begin{array}{l}\text { Pornografi atau } \\
\text { pornoaksi }\end{array}$ & $\begin{array}{c}\text { Tingkat } \\
\text { Kepentingan }\end{array}$ & Nilai \\
\hline Tidak Benar & Sangat Rendah & 1 \\
\hline Benar & Sangat Tinggi & 50 \\
\hline
\end{tabular}

Berikut diambil sampel 5 orang siswa yang akan digunakan sebagai alternatif dan diuji berdasarkan kriteria yang telah ditentukan diatas.

Tabel 11. Alternatif

\begin{tabular}{|c|c|}
\hline Alternatif & Keterangan \\
\hline $\mathrm{X} 1$ & Siswa1 \\
\hline $\mathrm{X} 2$ & Siswa2 \\
\hline $\mathrm{X} 3$ & Siswa3 \\
\hline $\mathrm{X} 4$ & Siswa4 \\
\hline $\mathrm{X} 5$ & Siswa5 \\
\hline
\end{tabular}

Berdasarkan sampel data yang diambil dari guru BK pada SMK As-Shofa Kabupaten Tasikmalaya maka di dapat nilai dari masing-masing alternatif dari kriteria berdasarkan tingkat kepentingan:

Tabel 12. Nilai alternatif berdasarkan kriteria

\begin{tabular}{|c|c|c|c|c|c|}
\hline \multirow{2}{*}{ Alternatif } & \multicolumn{5}{|c|}{ Kriteria } \\
\cline { 2 - 6 } & $\mathrm{C} 1$ & $\mathrm{C} 2$ & $\mathrm{C} 3$ & $\mathrm{C} 4$ & $\mathrm{C} 5$ \\
\hline $\mathrm{A} 1$ & 2 & 1 & 15 & 30 & 1 \\
\hline $\mathrm{A} 2$ & 2 & 4 & 15 & 1 & 1 \\
\hline $\mathrm{A} 3$ & 2 & 1 & 1 & 30 & 1 \\
\hline $\mathrm{A} 4$ & 1 & 1 & 15 & 30 & 1 \\
\hline A5 & 2 & 1 & 1 & 1 & 50 \\
\hline
\end{tabular}


Berdasarkan tabel nilai alternatif berdasarkan kriteria dibuat Matrik Keputusan (x)

$X=\left[\begin{array}{ccccc}2 & 1 & 15 & 30 & 1 \\ 2 & 4 & 15 & 1 & 1 \\ 2 & 1 & 1 & 30 & 1 \\ 1 & 1 & 15 & 30 & 1 \\ 2 & 1 & 1 & 1 & 50\end{array}\right]$

Lakukan Normalisasi terhadap Matrik Keputusan (X)

C1: Mengganggu ketenangan KBM

$r_{11} \frac{\min \{2 ; 2 ; 2 ; 1 ; 2\}}{2}=\frac{1}{2}=0,5$

$r_{21} \frac{\min \{2 ; 2 ; 2 ; 1 ; 2\}}{2}=\frac{1}{2}=0,5$

$r_{31} \frac{\min \{2 ; 2 ; 2 ; 1 ; 2\}}{2}=\frac{1}{2}=0,5$

$r_{41} \frac{\min \{2 ; 2 ; 2 ; 1 ; 2\}}{1}=\frac{1}{1}=1$

$r_{51} \frac{\min \{2 ; 2 ; 2 ; 1 ; 2\}}{2}=\frac{1}{2}=0,5$

C2: Bertindak Tidak Sopan Kepada Sesama Siswa

$r_{12} \frac{\min \{1 ; 4 ; 1 ; 1 ; 1\}}{1}=\frac{1}{1}=1$

$r_{22} \frac{\min \{1 ; 4 ; 1 ; 1 ; 1\}}{4}=\frac{1}{4}=0,25$

$r_{32} \frac{\min \{1 ; 4 ; 1 ; 1 ; 1\}}{1}=\frac{1}{1}=1$

$r_{42} \frac{\min \{1 ; 4 ; 1 ; 1 ; 1\}}{1}=\frac{1}{1}=1$

$r_{52} \frac{\min \{1 ; 4 ; 1 ; 1 ; 1\}}{1}=\frac{1}{1}=1$

C3: Membawa/ merokok di sekolah/ diluar sekolah

$r_{13} \frac{\min \{15 ; 15 ; 1 ; 15 ; 1\}}{15}=\frac{1}{15}=0,067$

$r_{23} \frac{\min \{15 ; 15 ; 1 ; 15 ; 1\}}{15}=\frac{1}{15}=0,067$

$r_{33} \frac{\min \{15 ; 15 ; 1 ; 15 ; 1\}}{1}=\frac{1}{1}=1$

$r_{43} \frac{\min \{15 ; 15 ; 1 ; 15 ; 1\}}{15}=\frac{1}{15}=0,067$ $r_{53} \frac{\min \{15 ; 15 ; 1 ; 15 ; 1\}}{1}=\frac{1}{1}=1$

C4: Membawa senjata tajam, senjata api dan sejenisnya

$r_{14} \frac{\min \{30 ; 1 ; 30 ; 30 ; 1\}}{30}=\frac{1}{30}=0,033$

$r_{24} \frac{\min \{30 ; 1 ; 30 ; 30 ; 1\}}{1}=\frac{1}{1}=1$

$r_{34} \frac{\min \{30 ; 1 ; 30 ; 30 ; 1\}}{30}=\frac{1}{30}=0,033$

$r_{44} \frac{\min \{30 ; 1 ; 30 ; 30 ; 1\}}{30}=\frac{1}{30}=0,033$

$r_{54} \frac{\min \{30 ; 1 ; 30 ; 30 ; 1\}}{1}=\frac{1}{1}=1$

C5: Pornografi atau pornoaksi

$r_{15} \frac{\min \{1 ; 1 ; 1 ; 1 ; 50\}}{1}=\frac{1}{1}=1$

$r_{25} \frac{\min \{1 ; 1 ; 1 ; 1 ; 50\}}{1}=\frac{1}{1}=1$

$r_{35} \frac{\min \{1 ; 1 ; 1 ; 1 ; 50\}}{1}=\frac{1}{1}=1$

$r_{45} \frac{\min \{1 ; 1 ; 1 ; 1 ; 50\}}{1}=\frac{1}{1}=1$

$r_{55} \frac{\min \{1 ; 1 ; 1 ; 1 ; 50\}}{50}=\frac{1}{50}=0,02$

Berdasarkan perhitungan matrik ternormalisasi diatas diperoleh matrik $(\mathrm{R})$ sebagai berikutt :

$\mathrm{R}=\left[\begin{array}{ccccc}0,5 & 1 & 0,067 & 0,033 & 1 \\ 0,5 & 0,25 & 0,067 & 1 & 1 \\ 0,5 & 1 & 1 & 0,033 & 1 \\ 1 & 1 & 0.067 & 0,033 & 1 \\ 0,5 & 1 & 1 & 1 & 0,02\end{array}\right]$

3. Menentukan bobot Preferensi

Bobot Preferensi (W) :

Tabel 13. Bobot Preferensi

\begin{tabular}{|c|c|}
\hline Kriteria & Bobot Nilai \\
\hline $\mathrm{C} 1$ & 1 \\
\hline $\mathrm{C} 2$ & 2 \\
\hline $\mathrm{C} 3$ & 3 \\
\hline $\mathrm{C} 4$ & 5 \\
\hline $\mathrm{C} 5$ & 5 \\
\hline
\end{tabular}

$\mathrm{W}=[1,2,3,5,5]$ 
4. Melakukan Perangkingan

Setelah matrik ternormalisasi didapat maka proses selanjutnya melakukan perangkingan $\left(\mathrm{V}_{\mathrm{i}}\right)$. proses perangkingan dilakukan dengan cara mengalikan bobot referensi (W) dengan matrik ternormalisasi (R).

$$
\begin{aligned}
\mathrm{V}_{1}= & (1)(0,5)+(2)(1)+(3)(0,067)+(5)(0,033)+(5)(1) \\
& 0,5+2+0,201+0,165+5 \\
& 7,866 \\
\mathrm{~V}_{2}= & (1)(0,5)+(2)(0,25)+(3)(0,067)+(5)(1)+(5)(1) \\
& 0,5+0,5+0,201+5+5 \\
& 11,201 \\
\mathrm{~V}_{3}= & (1)(0,5)+(2)(1)+(3)(1)+(5)(0,003)+(5)(1) \\
& 0,5+2+3+0,015+5 \\
& 10,665 \\
& \\
\mathrm{~V}_{4}= & (1)(1)+(2)(1)+(3)(0,067)+(5)(0,033)+(5)(1) \\
& 1+2+0,201+0,165+5 \\
& 8,366 \\
\mathrm{~V}_{5}= & (1)(0,5)+(2)(1)+(3)(1)+(5)(1)+(5)(0,02) \\
& 0,5+1+1+1+0,02 \\
& 10,6
\end{aligned}
$$

\section{Hasil Perangkingan}

Dari proses perhitungan perangkingan diatas, nilai tertinggi berada pada $V_{2}=11,201$. Perangkingan poin pelanggaran masing-masing siswa secara keseluruhan dapat dilihat pada tabel 14 :

Tabel 14. Peringkat Perangkingan

\begin{tabular}{|c|c|c|c|}
\hline Alternatif & $\begin{array}{c}\text { Nama } \\
\text { Siswa }\end{array}$ & $\begin{array}{c}\text { Poin } \\
\text { Pelanggaran }\end{array}$ & Keterangan \\
\hline A2 & Siswa 2 & 11,201 & Peringkat I \\
\hline A3 & Siswa 3 & 10,665 & Peringkat II \\
\hline A5 & Siswa 5 & 10,6 & Peringkat III \\
\hline A4 & Siswa 4 & 8,366 & Peringkat IV \\
\hline A1 & Siswa 1 & 7,866 & Peringkat V \\
\hline
\end{tabular}

Rancangan Database Sistem Informasi

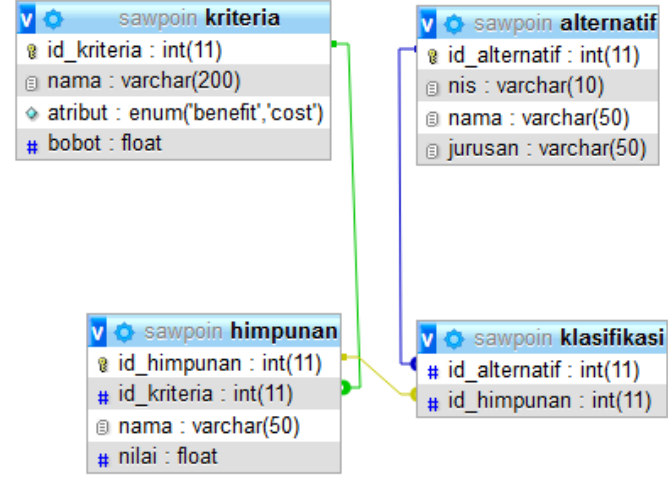

Gambar 2. Database

Rancangan Sistem Informasi

1. 1. Halaman Utama

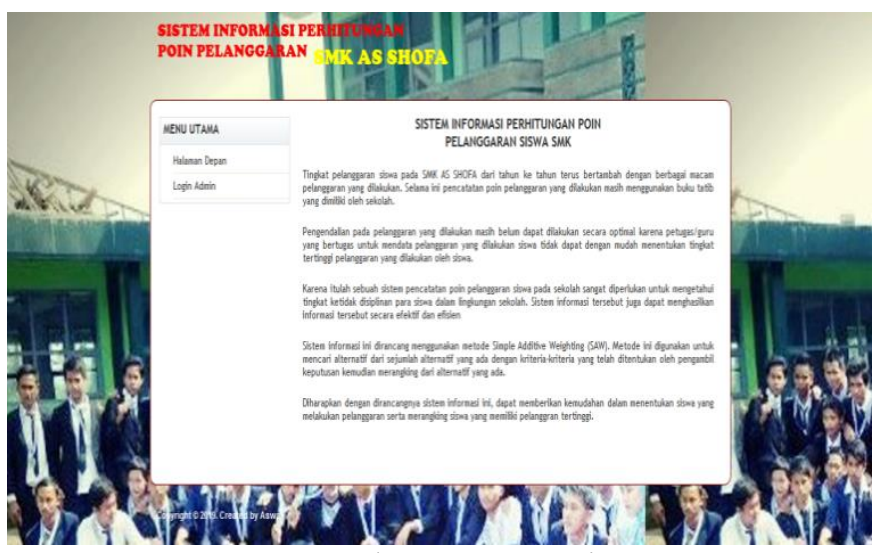

Gambar 3. Halaman Utama Sistem

2. 2. Halaman Login

3.

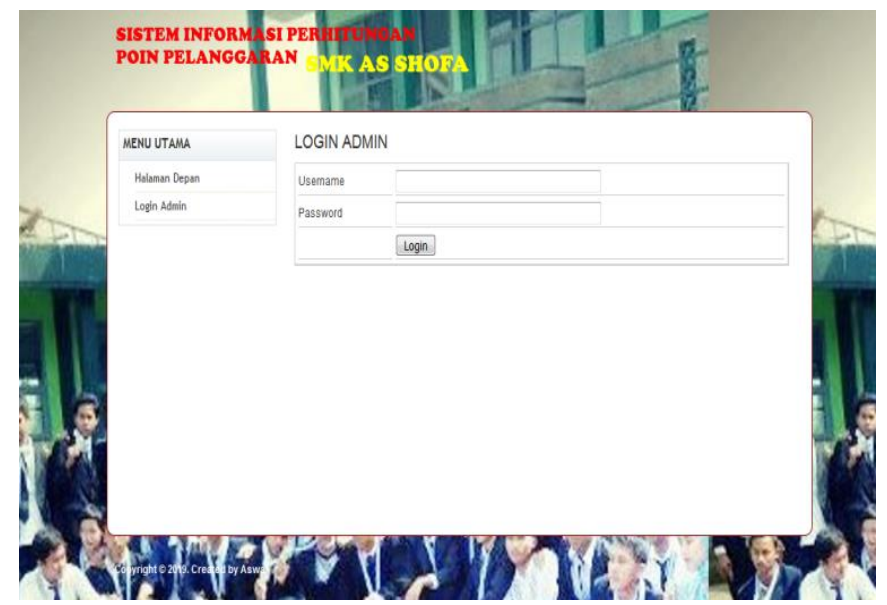

Gambar 4. Halaman Login Sistem 
3. Halaman Admin

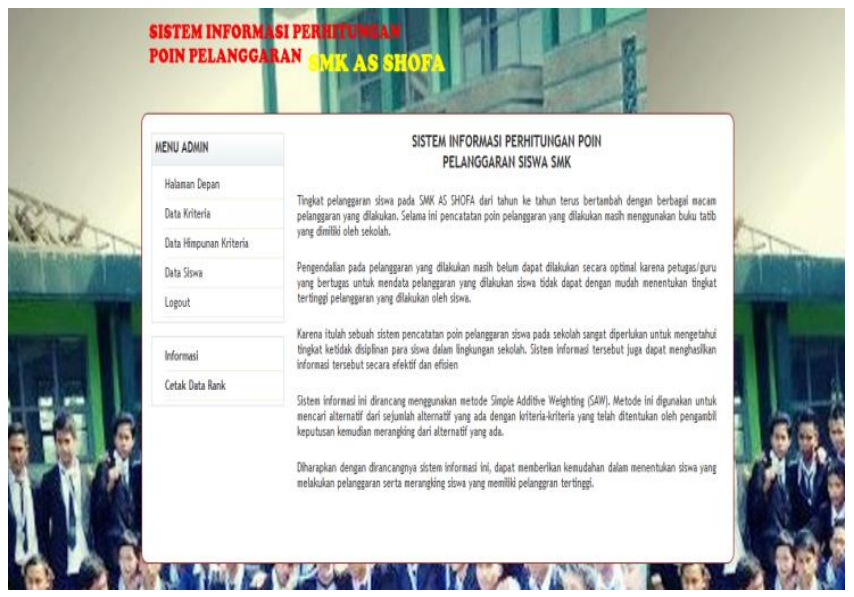

Gambar 5. Halaman Admin Sistem

4. Laporan Poin Pelanggaran Siswa

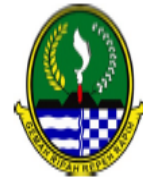

YAYASAN AS.SHOFA SNDANGKARAMAT SMIKAS.SHOFA

SR. No.14194421.5.DisdilibudDikmen 2003

Alamat: Pesanten As-Shofa J. Cilampunghilir Kec. Padakembang Tasilkmalaya 46466 Jawa Barat Tlp.Fax.(0265) 549072 e.mail : smbasshotalayahoo.com

LAPORAN PON PELANGGARAN SISWA

\begin{tabular}{|c|c|c|c|c|c|}
\hline No & NIS & NAMA & KELLSIJURUSAN & PONN & RANK \\
\hline 1 & 10001 & Siwwa I & Alwmansi & 7.866 & 5 \\
\hline 2 & 10002 & Siswa II & Fammasi & 11.201 & 1 \\
\hline 3 & 10003 & Siswa II & IKJ & 10.665 & 2 \\
\hline 4 & 10004 & Siswa IV & TKJ & 8.366 & 4 \\
\hline 5 & 10005 & Siswa & RPL & 10.6 & 3 \\
\hline
\end{tabular}

Gambar 6. Laopran Point Pelanggaran Sistem

\section{Kesimpulan}

Dengan aplikasi perhitungan poin pelanggaran siswa menggunakan metode simple additive weighting (SAW) dapat membantu guru BK dalam melakukan pencatatan dan merekapitulasi poin pelanggaran serta dapat mempercepat proses penindaklanjuatan terhadap siswa yang bermasalah.

\section{Daftar Pustaka}

[1] Y. Sopyan, S. Supriyadi, and E. Kurniadi, "Implementasi Sistem Pendukung Keputusan Penerimaan Siswa Baru Menggunakan Metode Simple Additive Weighting. (Study Kasus : Smk
Negeri 3 Kuningan)," vol. 11, no. 1, pp. 53-61, 2016.

[2] R. H. Khouf, "Sistem Pendukung Keputusan Kelayakan Calon Penerima Bantuan Bedah Rumah Di Kecamatan Sambirejo Dengan Menggunakan Metode Simple Additive Weighting," 2017.

[3] C. Surya, "Sistem Pendukung Keputusan Rekomendasi Penerima Beasiswa Menggunakan Fuzzy Multi Attribut Decision Making (FMADM) dan Simple Additive Weighting (SAW)," $J$. Rekayasa Elektr., vol. 11, no. 4, pp. 149-156, 2015.

[4] A. Setiadi et al., "Penerapan Metode Simple Additive Weighting ( SAW ) Untuk Pemilihan Siswa Terbaik," vol. 7, no. September, pp. 104109, 2018.

[5] A. A. Azhari, A. Najib, and T. Informasi, "Perbandingan Metode Saw dan Topsis Pada Penerimaan Siswa Praktek Kerja Lapangan," vol. 3, no. 1, pp. 71-77, 2018.

[6] E. Ismanto, "SATIN - Sains dan Teknologi Informasi Sistem Pendukung Keputusan Penerimaan Karyawan Dengan Metode Simple Additive Weighting ( SAW ), ”vol. 3, no. 1, pp. 19, 2017.

[7] D. Kartiko, "Sistem pendukung keputusan pemberian beasiswa di pt.indomarco prismatama cabang bandung," no. 114 . 